Jurnal Akuntansi dan Investasi, Vol. 17 No. 2, pages: 118-131, July 2016

This article available in website: http://journal.umy.ac.id/index.php/ai

DOI: 10.18196/jai.2016.0049.118-131

\title{
The Effect of Financial and Non-Financial Variables to Firm Performance: Comparison Between Indonesia and Thailand
}

\author{
Hasni Yusrianti ${ }^{12 *}$; Tien Norma Habsari': Suthawan Prukumpai ${ }^{3}$ \\ 'Program Studi Akuntansi Universitas Sriwijaya, Jl. Raya Palembang - Prabumulih Km 32, Sumsel, Indonesia \\ ${ }^{2}$ Program Studi Akuntansi Universitas Diponegoro, Jl. Prof. Soedarto, SH, Tembalang, Semarang, Jateng, Indonesia \\ ${ }^{3}$ Accounting Department of Kasetsart University, 50 ถนนงามวงศำน Lat Yao, เขตจตุจักร กรุงเทพฯ Bangkok 10900, Thailand
}

\section{A R T I C LE IN FO}

\section{Article history:}

received 21 Jan 2016

revised 13 Mar 2016

accepted 1 Apr 2016

\section{Keywords: \\ Financial; Non \\ Financial; Corporate \\ Social Responsibility; \\ Firm Performance}

\begin{abstract}
A B S T RACT
The purpose of this research is to test the effect of financial and non-financial variables to firm performances comparison between Indonesia and Thailand. The observation data used in this study is manufacturing companies from manufacturing sectors. Secondary data was used, collected from Indonesia Stock Exchange and Stock Exchange of Thailand during 2011 - 2013. By combining 3 years research, there are 55 Indonesian companies and 50 Thailand companies that meet predetermined criteria. Multiple Regression was used to analyze. This study uses Return on Equity, Earnings per Share, Market Value Added as financial variables and Earnings Quality, Institutional Ownership, Independent Commissioner, Audit Committee, Corporate Social Responsibility as non-financial variables. Test results show that both financial and non-financial variables can effect to firm performance.
\end{abstract}

(C) 2016 JAI. All rights reserved

\section{INTRODUCTION}

Capital markets have an important influence in supporting economy of a country. The capital market is a vehicle to invest their funds, especially for investors. So, the investor should know about firm performance to determine the companies prospect. Fundamental analysis that influenced by the financial variables is one indicator of company's financial performance. There are traditional financial performance and modern financial performance. Traditional financial performance such as return on equity and earnings per share are really important and usually center of attention of investors. Establishing company has several objectives, such as achieving maximum benefit or profit as much as possible, giving prosperity to owner and shareholder, and maximizing firm value (Martono and Harjito, 2005).

However, developments in science rapidly and the demands of the world market economy encouraged the experts to find and develop other measurement tools are more accurate in measuring company's performance. Therefore, in 1989, Stern Steward Consultant Management Service in the United States introduced the concept of Economic Value Added (EVA) and Market Value Added (MVA) as a measurement of modern financial performance and the market to overcome the shortcomings of traditional financial performance because according to Dodd and Chen (1996) in Siegel (2006) that EVA and MVA have performance measure in the belief that the company's EVA correlate between performance management with stock returns. Moreover compared with other performance measurements such as Return on Capital (ROC), Return on Equity (ROE), Earning per Share (EPS), cash flow growth, and Economic Value Added (EVA) have higher correlation in creating value for shareholders.

Moreover, besides financial performances, non financial variables also have effect to firm performance. Both financial and non-financial are useful to evaluate firm performance, and non-financial factors have additional explanatory power to financial factors, therefore the investor may consider it as supplementary information. Non financial variables can be measured by corporate governance and corporate social responsibility. Earnings quality, institutional ownership, independent commissioner and audit committee are proxy of corporate governance. Corporate governance mechanism aims to ensure and oversee the passage of governance systems in an organization (Walsh and Schward, 1990 cited by Sudiyanto, 2011). Furthermore, Corporate social responsibility is another indicator to measure non financial performance. International Organiza- 
Table 1. Comparison Indonesia Index \& Thailand Index

\begin{tabular}{ccccccc}
\hline \multirow{2}{*}{ YEAR } & \multicolumn{3}{c}{ IDX INDONESIA } & \multicolumn{3}{c}{ SET THAILAND } \\
\cline { 2 - 7 } & Highest & Lowest & Dif & Highest & Lowest & Dif \\
\hline 2013 & 5225,59 & 3994,46 & 1231,13 & 1631,27 & 1275,76 & 355,51 \\
2012 & 4224,51 & 3832,12 & 392,39 & 1239,06 & 1094,15 & 144,91 \\
2011 & 4174,12 & 3346,06 & 828,06 & 1043,24 & 995,33 & 47,91 \\
\hline
\end{tabular}

tion for Standardization (ISO) which adopted to determine corporate social responsibility is an international body as leading developer of international standards organization that was founded in 1947 with 154 states of member - has formulated a standard that is called ISO 26000: Guidance Standard on Social Responsibility that was released on November, $1^{\text {st }}$ 2010. The scope of ISO 26000 will spur companies in the world, including Indonesia, to conduct programs of social responsibility correctly. It is designed to be used by all types of organizations, whether for profit or non-profit company. Additionally, the good governance of company is currently in main concern.

As Southeast Asia countries, Indonesia and Thailand has a close relationship country. Although we have different country system, we also have some similarity. Looking back at the history data of SET Index in Thailand and IDX Index in Indonesia, the stock exchange index for the last 3 (three) years as showed at Table 1. Based on at that table, the differences between the highest and the lowest index either in Thailand or in Indonesia is quite significant. Since 2011 to 2013 , the differences between the highest index and the lowest index has a significant number. The highest index in Indonesia is 5225,59 in 2013, however the lowest one is 3994,46. Although the SET index is not as high as IDX index, the index is getting higher and the differences is getting bigger.

Since the previous studies provide mixed evidence. This research has objective to test the effect of financial and non-financial variables to firm performances. It is a comparative study about the relationship between financial and non financial variables on firm performance between Indonesia and Thailand. This research focuses on manufacturing companies with the consideration that the manufacturing sectors have different sensitivities to changes in economic conditions (Tuasikal, 2002) in Sugiyanto (2011).

The contributions of this research are as follows; (1) this paper uses not only the traditional financial variables but also includes the modern financial variables; (2) the non-financial variables such as Corporate Governance and Corporate Social Responsibility are considered in this paper, and (3) it provides comparative evidence between Indonesian and Thailand perspective.

\section{LITERATURE REVIEW AND HYPOTHESIS DEVELOPMENT}

\section{Agency Theory}

Agency Theory explains that separation between owner as principal and management as agent in running company will create some problems. Conflict of interest between principle and agent will be difficult to be avoided. Applying corporate governance mechanism is one of ways that can be done. Agency relationship is defined as a contract in which parties called owners or shareholders appoint another parties called agents or management to do some work on behalf of the owner. It includes the delegation of authority to make decisions (Brigham and Houston, 2006). In this study, management is expected by the owner to be able to optimize the existing resources in company maximally.

\section{Stakeholder Theory}

An entity is not a company that only operates for its own interests, but also should provide benefits for other stakeholders (shareholders, creditors consumers, suppliers, government, society). Thus, the existence of a company is influenced and determined by support given to the stakeholders (Ghozali and Chariri, 2007). Therefore, when stakeholder controls important economic resource of company, company will react in ways that satisfy the desires of stakeholder (Ullman, 1982 in Ghozali and Chariri, 2007). This research analysis both financial and financial performance that have many interest and parties, so this research is further referred to as stakeholder approach.

\section{Legitimacy Theory}

Legitimacy theory is theory based on the social contract between company and communities where it operates and uses economic resources (Sayekti and Wondabio, 2007). Ghozali and Chariri (2007) expla- 
ined that legitimacy theory is very useful in analyzing the behavior of the organization. The constraints imposed by norms, social values, and reaction of restrictions encourage the importance of organizational behavior analysis with respect to the environment. Disclosure of corporate social responsebility is to get a positive value and legitimacy from public, so this research is further referred to as legitimacy approach.

\section{Return on Equity (ROE)}

Return on Equity (ROE) is the ratio of net income to total equity. The higher of ROE indicates more efficiently the company uses its own capital to generate profit or net profit. $\mathrm{ROE}$ is used to measure the rate of return on the company or the effectiveness of the company in profit using shareholders' equity owned by the company (Ardimas and Wardoyo, 2014).

\section{Earnings per Share (EPS)}

Earnings per share is computed by dividing earnings after interest, the depreciation and tax by total number of outstanding shares. Dividend may be distributed out of these earnings; whether it is distributed as dividend to shareholders or not, it belongs to the shareholders. Hence earning per share is a measure which the stock brokers and investors will watch carefully and consider it while deciding the market value of the equity share (Nazaruddin, 2000).

\section{Market Value Added (MVA)}

The main objective of the company is to maximize shareholder's wealth. This goal can be realized in a way to maximize firm value (Market Value of Firm). Maximize firm value equal to the share price maximization. Prosperity shareholders can be maximized by maximizing the difference between the market value of equity to equity (own capital) are submitted to the company by the shareholders (owners of the company). The differrence is called the Market Value Added (MVA) (Husnan and Pudjiastuti, 2004).

\section{Corporate Governance}

Corporate governance is a set of mechanisms that direct and control enterprise in order to run company operations in accordance to the stakeholder's expectations. Good corporate governance is the structures, systems, and processes used by the organs of company in an effort to provide sustainable value added in long term by taking into account the interests of other stakeholders based on norms, ethics, cultures, and regulations (The Indonesian Institute for Corporate Governance).

\section{Corporate Governance Mechanism}

Corporate governance mechanism is divided into two groups, internal and external control mechanism. First, internal control mechanism is a way to control company using internal structures and processes, such as the composition of board of directors or commissioners, managerial ownership, and executive compensation. Second, external control mechanism is a way to affect company using external factors, such as market control and debt financing level (Barnhart and Rosenstein, 1998).

Corporate governance mechanism used in this study is internal control mechanism. It is proxied by earnings quality, institutional ownership, independent commissioners, and audit committee.

(1) Earnings Quality (EQ),

Earnings quality is a key characteristic of financial reporting. Dechow et al. (2010) said that higher quality earnings provide more information about the features of a firm's financial performance that are relevant to a specific decision made by a specific decision-maker.

(2) Institutional Ownership (IO)

According to Adrian Sutedi (2011), institutional ownership is ownership of shares that owned by institutions such as insurance companies, banks, investment companies, foundations, pension funds, and others. It has very important role in minimizing agency conflict between manager and shareholder.

(3) Independent Commissioner

Independent commissioners are all of commissioners who do not have any substantial business interests in the company. Independent commissioners serve as a counterweight in decision making.

(4) Audit Committee

The purposes of establishing audit committee are ensuring that financial statements are not misleading and issued in accordance with generally accepted accounting principles, ensuring internal control is adequate, following up allegations of material irregularities in finance and its legal implications, and recommending external auditor. 


\section{Corporate Social Responsibility}

The definition of social responsibility based on ISO 26000: Global Guidance Standard on Social Responsibility is responsibility of an organization for the impacts of its decisions and activities on society and environment, through transparent and ethical behavior that contributes to the sustainable development, health, and society welfare; takes into account the expectations of stakeholders; that is in compliance with applicable law and consistent with international norms of behavior; and that is integrated throughout the organization and practiced in its relationships.

ISO 26000 is a voluntary guidance standard on social responsibility that is designed to used by all types of organizations, whether for profit or nonprofit organizations. ISO 26000 provides guidance rather than requirements or standardization. Therefore, it cannot be certified like some other wellknown ISO standards. It provides guidance on how organization can operate in a socially responsible way, act in an ethical and transparent way that contributes to the health and social welfare.

\section{Disclosure of Corporate Social Responsibility}

In recent years, the growth of public awareness about company role has increased. It can be seen from the number of companies that are considered having high contribution to economic and technology progress, but they still has been criticized for creating some social problems. Pollution, resource depletion, waste, quality and product safety, and employee's rights are issues of public concerns.

ISO 26000: Guidance Standard on Social Responsibility identifies seven core subjects where social responsibility should be addressed. In order to identify what they do in their current practices and to set priorities for improvements, implementers of ISO 26000 should evaluate their actions in each subject. These are; Organizational governance; Human rights; Labor practices; Environment; Fair operating practices; Consumer issues; and Community involvement and development.

\section{Firm Performance}

There are several objectives of establishing a company, such as achieving maximum benefit or profit as much as possible, giving prosperity to the owner and shareholders, and maximizing firm performance that is reflected in its stock price. Actually, three company goals are not substantially different. Only the emphasis that to be achieved by each company is not same (Martono and Harjito, 2005). Firm performance is essentially measured from several aspects. According to Fama (1978) cited by Wahyudi dan Pawestri (2006), firm value is reflected in its stock price. It is because market price of com-pany stock reflects investor's assessment for overall equity held. According to Rahayu (2010), firm value describes how well management manage the wealth. A company will try to maximize firm value. Incre-asing firm value is usually characterized by increasing stock prices in the market.

\section{Relationship Between Return on Equity and Firm Performance}

One company operates is useful to generate profits for shareholders. The size of the successful achievement of these reasons is the number ROE achieved. The bigger the ROE reflects the company's ability to generate high returns for shareholders. Research by Ardimas and Wardoyo (2014) stated that ROE have a significant effect on firm value. Moreover, Febriana (2013) indicated that ROE has positively significant to firm value and CSR can not approve that the relationship between ROE to firm value and research of Amri (2011) also stated that ROE and CSR have a significant effect on firm value. Although the results has shown significant result, to prove these finding between Indonesia and Thailand, the hypothesis is as follows:

$\mathrm{H}_{\iota . .}$ : The existence of Return on Equity affect firm performance positively.

\section{Relationship Between Earnings per Share and Firm Performance}

Several studies have shown that the earnings quality will affect market response to corporate profits (Choi and Jeter, 1990). Implementation of good corporate governance is expected to improve the market's perception of the quality of corporate profits. Improving the earnings quality will be followed by increase market response to earnings surprises. Research by Yulistiana (2009) find that EPS has positively significant to firm performance. Although the results has shown significant result, to prove these finding between Indonesia and Thailand, so the hypothesis is as follows:

$\mathrm{H}_{\mathrm{l} . \mathrm{s}}$ : The existence of Earnings per Share affect firm performance positively.

\section{Relationship Between Market Value Added and Firm Performance}

The present value of the expected EVA is Market Value Added (MVA) which is the market 
value of debt and total equity capital of the company is used to support value-added. MVA is a measure used to measure success in maximizing shareholder value by allocating resources - the appropriate source. MVA also can measure how much wealth the company that has been created for investors or MVA express how much wealth has been achieved (Husniawati, 2004). Furthermore, Aditiya (2013) indicated that MVA has positively significant to firm performance. Although the results has shown significant result, to prove these finding between Indonesia and Thailand, the hypothesis is as follows: $\mathrm{H}_{\text {l.c }}$ : The existence of Market Value Added affect firm performance positively.

\section{Relationship Between Earnings Quality and Firm Performance}

Several studies about relationship between Earning Quality and Firm Performance have shown inconsistency result. Research by Choi and Jeter (1990) indicated that the earnings quality will affect market response to corporate profits. Implementation of good corporate governance is expected to improve the market's perception of the quality of corporate profits. Furthermore, Siallagan (2009) found that Earnings quality has negatively significant to firm performance. Mendra and Widanaputra (2012) indicated that corporate governance has significant positive influence to the performance of public companies. Based on these finding, the hypothesis is as follows:

$\mathrm{H}_{2 \wedge}$ : The existence of Earnings Quality affect firm performance positively.

\section{Relationship Between Institutional Ownership and Firm Performance}

Research by some researchers about Institutional Ownership and Firm Performance shows inconsistency result. Institutional ownership is ownership of substantial shares in company by an institution. High levels of institutional ownership will lead to greater business security conducted by institutional investors. It is caused they can deter opportunistic behaviors of manager. The higher ownership by financial institutions, it will increase firm value. Rachmawati and Triatmoko (2007) found that institutional ownership had significant and positive effect to firm value. Research by Debby et al. (2013) indicated that GCG does not affect firm value and Company characteristics have positive effect on firm value. Based on these finding, the hypothesis is as follows:

$\mathrm{H}_{2 \mathrm{~B}}$ : The existence of institutional ownership affect firm performance positively.
Relationship Between Independent Commissioners and Firm Performance

Independent commissioners are all of commissioners who do not have any substantial business interest in the company. They serve as a counterweight in decision making. They act solely for company interest that will increase firm value. Siallagan and Machfoedz (2006) proved that independent commissioners affected firm value positively and significantly. Furthermore, Mendra and Widanaputra (2012) indicated that corporate governance has significant positive influence to the performance of public companies. Although the results has shown significant result, to prove these finding between Indonesia and Thailand, the hypothesis is as follows: $\mathrm{H}_{2 .}$ : The proportion of independent commissioner affect firm performance positively.

\section{Relationship Between Audit Committee and Firm Performance}

One of indicators that can be used to determine the quality of audit committee is the frequency of their meeting. The more meeting frequency of audit committee, the better coordination of audit committee in conducting supervision. Therefore, it can ensure that their monitoring activities for management can run effectively. Research by Debby et al. (2013) indicated that GCG does not affect firm value and Company characteristics have positive effect on firm value. Furthermore, Mendra and Widanaputra (2012) indicated that corporate gover-nance has significant positive influence to the performance of public companies. Based on these finding, the hypothesis is as follows:

$\mathrm{H}_{2 \mathrm{D}}$ : The meeting frequency of audit committee affect firm performance positively.

\section{Relationship Between Disclosure of CSR and Firm Performance}

Several studies about relationship between Corporate Social Responsibility and Firm Performance have shown inconsistency result. Investors will consider CSR activities that are disclosed in company annual report before deciding whether to invest or not besides financial performance. CSR disclosure is expected to increase investor trust to the company prospect. It is in line with the research of Orlitzky et al. (2003) in Karim (2013) that used data from 52 researches with cases from 33.878 companies for 30 years, supporting argument that stated social performance and financial performance correlate positively. It will increase firm value. 
Furthermore, by implementing CSR, company expected will gain social legitimacy and maximize strength finances in long term (Kiroyan,2006). It indicates that market wili respond positively company that implement CSR. Ardimas and Wardoyo (2014) also stated that CSR have a significant effect on firm value. Research by Febriana (2013) indicated that CSR can not approve that the relationship between ROE to firm value. The researh result of Amri (2011) also stated CSR have a significant effect on firm value. Other result showed that Balabanis, Phillips, and Lyall (1998), shows that CSR is positively related to financial performance (gross profit to sales ratio / GPS), but negatively related to return on capital employed (ROCE). Based on these finding, the hypothesis is as follows:

$\mathrm{H}_{2 \mathrm{E}}$ : The disclosure of corporate social responsibility affect firm performance positively.

\section{RESEARCH METHOD}

\section{Observation}

The observation data used in this study is manufacturing sectors listed on the Indonesia Stock Exchange (IDX) and Stock Exchange of Thailand (SET) in 2011 until 2013. In 2013, the Indonesia Stock Exchange had 462 listed companies with a combined market capitalization of $\$ 426.78$ billion and in the Stock Exchange of Thailand (SET) had 584 listed companies with a combined market capitalization of THB 11,496 billion.

The criteria samples are: Shares of companies listed on the IDX \& SET for 3 years in a row and The company publishes the annual financial statements of the period 31 December 2011 until 31 December 2013. There were 55 companies in Indonesia and 50 companies in Thailand that represent the object of observation and meet the above requirements.

\section{Data and Sources}

Data used in this study is secondary data source from www.idx.co.id and www.set.ac.th and also from data stream. The data needed in this study include data from the manufacturing sectors as industrial group that go public during 2011-2013.

\section{Data Analysis}

The model equations are used as follows: $Y_{i}=\alpha+\beta_{1} R O E_{i}+\beta_{2}$ EPS $_{i}+\beta_{3} M_{V A}+e_{i} \ldots$

(Equation 1)

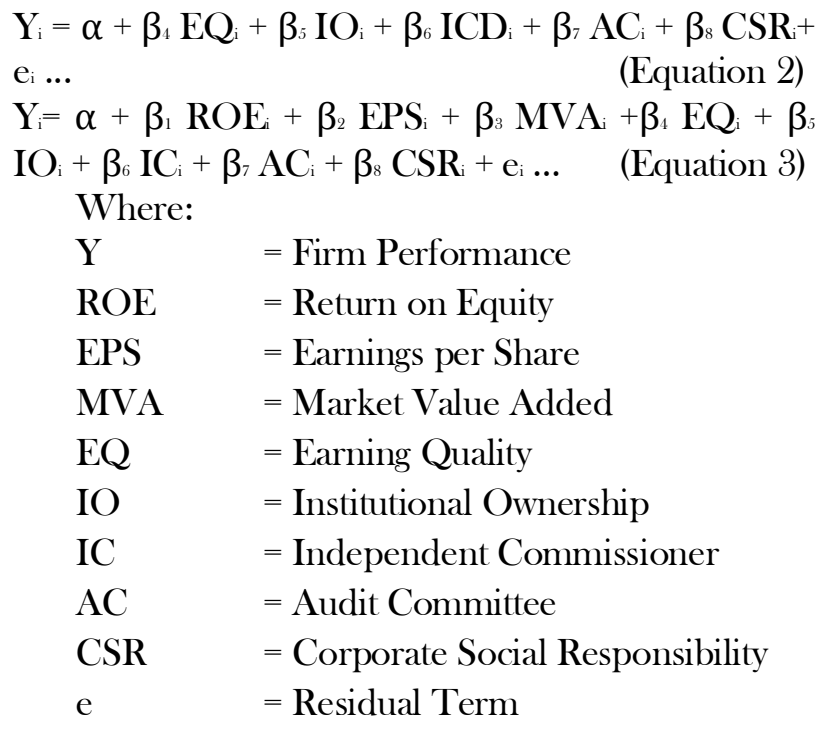

Analysis Technique

\section{Descriptive Statistics Analysis}

Descriptive statistics is used to analyze data in ways describing or depicting data that has been collected without any intention to make generally accepted conclusions or generalizations. It described in their minimum value, maximum value, mean, and standard deviation.

\section{Classical Assumptions Test}

Good regression model is a model that passes all of classical assumption test (Ghozali, 2009), includes Normality Test, Multi collinearity Test, Autocorrelation Test, and Heterocedastisity Test.

(1) Normality Test. It is done to determine whether research data or residual values of data have a normal distribution or not. Good regression model is model whose distribution of data is normal or close to normal.

(2) Multi collinearity Test. It aims to test whether there is a correlation among independent variables in the regression model. A good regression model should not have correlation among independent variables. In order to detect the existence multi collinearity in the regression model, it can be seen from the value of tolerance and the value of Variance Inflation Factor (VIF).

(3) Autocorrelation Test. It is a test to determine whether there is a correlation between a series of observation data that are sorted according to time and space. It means whether data in any given year is influenced by data in the previous year. However, this study does not use this test because this study uses the cross sectional data. 


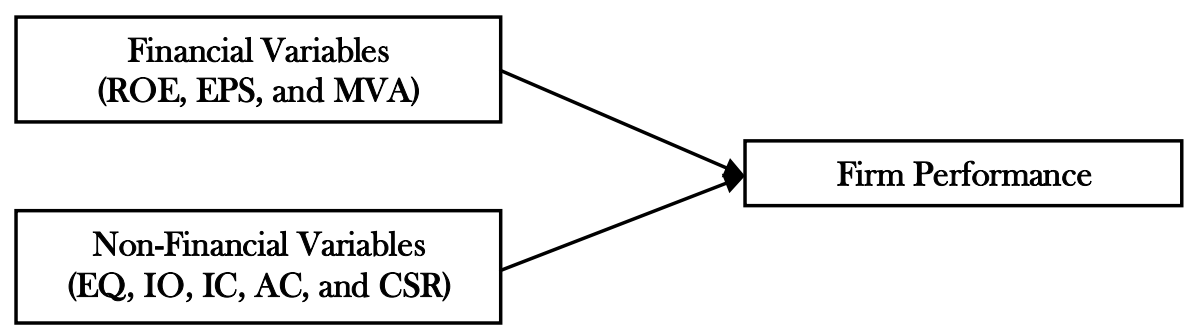

Figure 1. Research Model

Table 2. Variables Definition and Measurement

\begin{tabular}{|c|c|c|c|}
\hline No & Variable & Definition & Measurement \\
\hline 1 & Firm Performance & Tobin's $Q$ & Tobin's $^{\prime} Q=\frac{M V E+D}{B V E+D}$ \\
\hline 2 & Return on Equity (ROE) & $\begin{array}{l}\text { Return on equity or return on capital } \\
\text { is the ratio of net income of a busi- } \\
\text { ness during a year to its stockholders' } \\
\text { equity during that year. }\end{array}$ & $\frac{\sum \text { Net Income }}{\sum \text { shareholder's Equity }}$ \\
\hline 3 & Earnings per Share (EPS) & $\begin{array}{l}\text { Earnings per share (EPS) is The por- } \\
\text { tion of a company's profit allocated to } \\
\text { each outstanding share of common } \\
\text { stock. }\end{array}$ & Thomson Reuters Datastream \\
\hline 4 & $\begin{array}{l}\text { Market Value Added } \\
\text { (MVA) }\end{array}$ & $\begin{array}{l}\text { Market value added (MVA) is the } \\
\text { difference between the current mar- } \\
\text { ket value of a firm and the capital } \\
\text { contributed by investors. }\end{array}$ & $\mathrm{V}-\mathrm{K}$ \\
\hline 5 & Earnings Quality (EQ) & $\begin{array}{l}\text { Earnings quality is the quality of a } \\
\text { reported earnings number depends } \\
\text { on whether it is informative about the } \\
\text { firm's financial performance. }\end{array}$ & Thomson Reuters Datastream \\
\hline 6 & $\begin{array}{l}\text { Institutional Ownership } \\
\text { (IO) }\end{array}$ & $\begin{array}{l}\text { Ownership of substantial shares in } \\
\text { company by institutions. }\end{array}$ & $\frac{\sum \text { shareheld by institution }}{\sum \text { outstanding share }}$ \\
\hline 7 & $\begin{array}{l}\text { Independent Commissioner } \\
\text { (IC) }\end{array}$ & $\begin{array}{l}\text { All of commissioners who do not } \\
\text { have any substantial business interests } \\
\text { in the company. }\end{array}$ & $\frac{\sum \text { independent commissioner }}{\sum \text { commissioners }}$ \\
\hline 8 & Audit Committee (AC) & $\begin{array}{l}\text { Committee established by board of } \\
\text { commissioners in order to perform a } \\
\text { task of supervising management. }\end{array}$ & Ln (Frequency meeting in 1 year) \\
\hline 9 & CSR & $\begin{array}{l}\text { Information disclosed by company } \\
\text { associated with social activities. (Orga- } \\
\text { nize, governance, Human rights, } \\
\text { Labor practices, Environment, Fair } \\
\text { operating practices, Consumer issues, } \\
\text { Community involvement, and dev- } \\
\text { elopment }\end{array}$ & $C S R=\frac{n}{k}$ \\
\hline
\end{tabular}


(4) Heterocedastisity Test. It is a situation where there is inequality of regression model residual variance from one observation to other observations. It can be seen from the value of Prob* R-Squared. If Prob* R-Squared is higher than 0.05 , it can be concluded that there is no heterocedasticity.

\section{Regression Analysis}

(1) Simultaneous Significant Test (F-test)

$\mathrm{F}$ test basically shows whether all of independent variables included in regression model have an influence collectively or simultaneously on dependent variable.

(2) Partial Significant Test (t-test)

Basically, t-test shows how far the influence of independent variables in explaining dependent variable individually.

(3) $\mathbf{R}^{2}$ and the Adjusted $\mathbf{R}^{2}$

An important property of $\mathbf{R}^{2}$ is that it is a non decreasing function of the number of explanatory variables or regressors present in the model; as the number of regressors increases, $\mathrm{R}^{2}$ almost invariably increases and never decreases. Stated differently, an additional $X$ variable will not decrease $\mathbf{R}^{2}$.

\section{RESULTS AND DISCUSSION}

\section{Description of Research Object}

There are 55 companies in Indonesia and 50 companies in Thailand that represent the object of observation and meet the requirements.

\section{Data Analysis}

\section{Descriptive Statistics Analysis}

Descriptive statistics is used to analyze data in ways describing or depicting data without any intention to make generally accepted conclusions or generalizations (see Table 3 and 4). In this section, each variable that has been processed will be described in its minimum value, maximum value, mean value, and standard deviation.

Based on the results in Indonesia, Earnings per share have the biggest maximum value 4300 than others, while its minimum value -2537.21. Mean value of this variable is 181.64 with standard deviation of 595.03. For Thailand, Earnings per share have the biggest maximum value 120.50 than others. While its minimum value -16.19. Mean value of this variable is 3.02 with standard deviation of 11.26.

Table 3. Descriptive Statistics Analysis - Indonesia

\begin{tabular}{lccccc}
\hline & $\mathrm{N}$ & Minimum & Maximum & Mean & Std. Deviation \\
\hline Return on Equity & 165 & -1.500000 & 1.520000 & 0.053598 & 0.250464 \\
Earnings per Share & 165 & -2537.212 & 4300.000 & 181.6441 & 595.0397 \\
Market Value Added & 165 & -1.038080 & 3.384081 & 0.032382 & 0.604296 \\
Earnings Quality & 165 & 1.000000 & 93.00000 & 30.20122 & 27.42736 \\
Institutional Ownership & 165 & 0.000000 & 0.273900 & 0.020341 & 0.050976 \\
Independent Commissioner & 165 & 0.250000 & 0.500000 & 0.377972 & 0.079754 \\
Ln (Frequency Meeting of & 165 & 0.000000 & 4.564348 & 1.621326 & 0.601703 \\
Audit Committee) & & & & & \\
CSRD Index & 165 & 0.000000 & 1.000000 & 0.912986 & 0.187585 \\
Firm performance & 165 & -5.000000 & 11.92000 & 1.487744 & 2.071805 \\
Valid N (listwise) & 165 & & & & \\
\hline
\end{tabular}

Table 4. Descriptive Statistics Analysis - Thailand

\begin{tabular}{lccccc}
\hline & $\mathrm{N}$ & Minimum & Maximum & Mean & Std. Deviation \\
\hline Return on Equity & 150 & -1.143914 & 0.465779 & 0.069300 & 0.204920 \\
Earnings per Share & 150 & -16.19000 & 120.5000 & 3.020566 & 11.26951 \\
Market Value Added & 150 & -0.493463 & 2.536170 & 0.144121 & 0.487606 \\
Earnings Quality & 150 & 1.000000 & 97.00000 & 51.81379 & 29.39694 \\
Institutional Ownership & 150 & 0.000000 & 0.257300 & 0.022768 & 0.045621 \\
Ln (Frequency Meeting of Audit & 150 & 1.386294 & 2.564949 & 1.574042 & 0.328784 \\
Committee) & & & & & \\
CSRD Index & 150 & 0.837838 & 1.000000 & 0.942404 & 0.052844 \\
Firm performance & 150 & -1.730000 & 16.44000 & 1.756552 & 2.307000 \\
Valid N (listwise) & 150 & & & & \\
\hline
\end{tabular}


Higher earnings per share is always better than a lower ratio because this means the company is more profitable and the company has more profits to distribute to its shareholders.

Institutional ownership in Indonesia has the lowest maximum value 0.273 than others, while its minimum value of 0 . Mean value of this variable is 0.0203 or 2.03 percent with standard deviation of 0.05. It means that institutional investors have 2.03 percent of company share. For Thailand, Institutional ownership has the lowest maximum value 0.257 than others, while its minimum value of 0 . Mean value of this variable is 0.0227 or 2.27 percent with standard deviation of 0.045 . It means that institutional investors have 2.27 percent of company share. Larger institutional ownership is assumed can accelerate management to present good performance.

\section{Classical Assumptions Test}

Good regression model is a model that passes all of the classical assumption test (Ghozali, 2009), included Normality Test, Multicollinearity Test, Auto-correlation Test, and Heterocedastisity Test. From the tests that have been done, it can be concluded that there are no deviating results.

\section{Normality Test}

Normality test is done to determine whether research data or residual values of data have normal distribution or not. For Indonesia, Kurtosis is 8.87, It means that it's non-normal distribution. The standard normal distribution has a kurtosis of three, and $\beta_{2}-3$ is often used so that the reference normal distribution has a kurtosis of zero $\left(\beta_{2}-3\right.$ is sometimes denoted as $\Upsilon_{2}$ ), DeCarlo (1997).

For Thailand, the skewness for a normal distribution is zero, and any symmetric data should have a skewness near zero. It means that it's nonnormal distribution. It's skewed right because it has positive values for the skewness. Kurtosis is 10.28 , it means that it's non-normal distribution. The standard normal distribution has a kurtosis of three, and $\beta_{2}-3$ is often used so that the reference normal distribution has a kurtosis of zero $\left(\beta_{2}-3\right.$ is sometimes denoted as $\Upsilon_{2}$ ), De Carlo (1997). In addition, positive kurtosis indicates a "peaked" distribution.

\section{Multicollinearity Test}

According to Ghozali (2005), a good regression model does not contain multicollinearity if its tolerance value is higher than 0.1 (tolerance $>0.1$ ) or VIF is smaller than 10 (VIF $<10$ ). For Indonesia, there are two independent variables that have tolerance value less than 0.1 and there are no independent variables that have VIF more than 10 .
Although MVA and AC have VIF less than 10 which are 1.20 and 1.03 , but they have tolerance value less than 0.1 which are 0.06 and 0.05 . It can be concluded that there is correlation among indepen-dent variables so that multicollinearity did happen in this regression model. Because AC has probability 0.96, it's more than 0.05. It's not significant. Whereas MVA has probability 0.00, it's less than 0.05 , it's significant. So that $\mathrm{AC}$ was excluded from the regression model. There is one of independent variable that has tolerance value less than 0.1 which is MVA and there are no independent variables that have VIF more than 10 . It can be concluded that there is correlation among independent variables so that it has multicollinearity in this regression model.

However, for Thailand, there are two independent variables that have tolerance value less than 0.1 and there are no independent variables that have VIF more than 10. Although EPS and MVA have VIF less than 10 which are 1.08 and 1.24 , but they have tolerance value less than 0.1 which are 0.00 and 0.08. It can be concluded that there is correlation among independent variables so that multicolli-nearity did happen in this regression model. Because EPS has probability 0.59, it's more than 0.05, It is not significant. Whereas MVA has probability 0.00 , it's less than 0.05 , it's significant. So that EPS was excluded from the regression model. There is one of independent variable that has tolerance value less than 0.1 which is MVA and there are no independent variables that have VIF more than 10. It can be concluded that there is correlation among independent variables so that multicollinearity did happen in this regression model.

\section{Heterocedasticity Test}

Heterocedasticity test used white's general heterocedasticity. The white test regresses the squared residuals on the cross product of the original regressors and a constant. In Indonesian company, $\mathrm{Prob}^{*} \mathrm{R}$-square value is 61.41. Because of Prob ${ }^{*} \mathrm{R}$ square is higher than 0.05 , It can be concluded that there is no heteroscedasticity happened in this regression model. In Thailand company, Prob* Rsquare value is 97.90. Because of Prob* R-square is higher than 0.05 , It can be concluded that there is no heterocedasticity happened in this regression model.

\section{Multiple Regression Analysis}

Based on the classical assumption tests, it can be concluded that the data are distributed unnormally and multicollinearity, and there is no hetero- 
cedasticity happened in this regression model. These conditions fulfill the requirements to conduct multi-ple regression analysis in order to test hypotheses.

Table 5. Regression - Indonesia

\begin{tabular}{|c|c|c|c|}
\hline Variable & Model 1 & Model 2 & Model 3 \\
\hline \multirow[t]{2}{*}{ Intercept } & 1.361 & 2.857 & 2.322 \\
\hline & $(0.153)^{* * *}$ & $(1.356)^{* *}$ & $(1.223)^{*}$ \\
\hline \multirow[t]{2}{*}{$\mathrm{ROE}$} & -0.308 & & -0.225 \\
\hline & (0.608) & & (0.589) \\
\hline \multirow[t]{2}{*}{ EPS } & 0.0005 & & 0.001 \\
\hline & $(0.002)^{* *}$ & & $(0.000)^{* *}$ \\
\hline \multirow[t]{2}{*}{ MVA } & 1.564 & & 1.488 \\
\hline & $(0.2460)^{* * *}$ & & $(0.249)^{* * *}$ \\
\hline \multirow[t]{2}{*}{$\mathrm{EQ}$} & & -0.014 & -0.011 \\
\hline & & $(0.006)^{* *}$ & $(0.005)^{* *}$ \\
\hline \multirow[t]{2}{*}{$\mathrm{IO}$} & & 12.604 & 10.076 \\
\hline & & $(3.044)^{* * *}$ & $(2.779)^{* * *}$ \\
\hline \multirow[t]{2}{*}{ IC } & & -1.525 & 0.865 \\
\hline & & (2.107) & (1.933) \\
\hline \multirow[t]{2}{*}{ CSR } & & -0.665 & -1.300 \\
\hline & & (0.888) & $(0.805)$ \\
\hline Adj. R & 0.2071 & 0.1039 & 0.2795 \\
\hline Square & & & \\
\hline
\end{tabular}

As can be seen from Table 5, model 1 reveals the relationship between financial variables and firm performance of Indonesian dataset. The results show that EPS and MVA have positively significant relationship to the firm performance whereas the ROE does not have significant relationship to the firm performance. So, the statement of hypothesis 1 about financial variables (EPS and MVA) have positively significant to firm performance is accepted. Model 2 reveals the relationship between non-financial variables and firm performance of Indo-nesian dataset. The results show that EQ and IO have significant relationship even though EQ has negative effect to the firm performance. IC and CSR do not have significant relationship to the firm performance. So, the statement of hypothesis 2 about non-financial variable (IO) have positively significant to firm performance is accepted.

Model 3 reveals the relationship between financial and non-financial variables to firm performance of Indonesian dataset. The results show that EPS, MVA, and IO have positively significant relationship to the firm performance, while EQ has negatively significant relationship effect to the firm performance. ROE, IC and CSR do not have significant relationship to the firm performance. So, the statement of hypothesis 3 about financial (EPS and MVA) and non-financial variables (IO) have positively significant to firm performances is accepted.
The coefficient of Adjusted R Square of model 1 is 0.2071 . It means that 20.71 percent of firm performance can be explained by return on equity, earnings per share, market value added as independent variables, while the rest can be explained by other factors. However, the coefficient of Adjusted $\mathrm{R}$ Square of model 2 is 0.1039 . It means that 10.38 percent of firm performance can be explained by earnings quality, institutional ownership, independent commissioner, and corporate social responsibility as independent variables, while the rest can be explained by other factors.

Furthermore, the coefficient of Adjusted $\mathbf{R}$ Square of model 3 is 0.2795 . It means that 27.95 percent of firm performance can be explained by return on equity, earnings per share, market value added, earnings quality, institutional ownership, independent commissioner, and corporate social responsibility as independent variables, while the rest can be explained by other factors. Based on the three models in this study, model (3) has the most goodness of fit. The third model has the highest value of adjusted $\mathrm{R}$ square of 0.2795 , whereas the first model of 0.2071 and a second model of 0.1038 . It means that 27.95 percent of firm performance can be explained by financial and non-financial variables as independent variables, while the rest can be explained by other factors.

Table 6. Regression - Thailand

\begin{tabular}{|c|c|c|c|}
\hline Variable & Model 1 & Model 2 & Model 3 \\
\hline \multirow[t]{2}{*}{ Intercept } & 1.3039 & -4.561 & -5.562 \\
\hline & $(0.146)^{* * *}$ & $(3.501)$ & $(2.460))^{* *}$ \\
\hline \multirow[t]{2}{*}{$\mathrm{ROE}$} & -0.0311 & & -0.678 \\
\hline & $(0.732)$ & & $(0.725)$ \\
\hline \multirow[t]{2}{*}{ EPS } & -0.007 & & -0.006 \\
\hline & $(0.012)$ & & $(0.012)$ \\
\hline \multirow[t]{2}{*}{ MVA } & 3.354 & & 3.503 \\
\hline & $(0.301)^{* * *}$ & & $(0.295)^{* * *}$ \\
\hline \multirow[t]{2}{*}{ EQ } & & 0.013 & 0.009 \\
\hline & & $(0.006)^{* *}$ & $(0.005)^{*}$ \\
\hline \multirow[t]{2}{*}{$\mathrm{IO}$} & & -1.417 & -6.524 \\
\hline & & $(4.160)$ & $(2.950)^{* *}$ \\
\hline \multirow[t]{2}{*}{$\mathrm{AC}$} & & -0.462 & -0.347 \\
\hline & & $(0.575)$ & $(0.408)$ \\
\hline \multirow[t]{2}{*}{ CSR } & & 6.783 & 7.556 \\
\hline & & $(3.533)^{*}$ & $(2.496)^{* * *}$ \\
\hline Adj. R Square & 0.4990 & 0.039 & 0.549 \\
\hline
\end{tabular}

As can be seen from Table 6, model 1 reveals the relationship between financial variables and firm performance of Thailand dataset. The results show that MVA has positively significant relationship to the firm performance whereas the ROE and EPS do 
not have significant relationship to the firm performance. So, the statement of hypothesis 1 about financial variable (MVA) has positively signifycant to firm performance is accepted. Model 2 reveals the relationship between non-financial variables and firm performance of Thailand dataset. The results show that EQ and CSR have positively significant relationship to the firm performance. IO and $\mathrm{AC}$ do not have significant relationship to the firm performance. So, the statement of hypothesis 2 about nonfinancial variables (EQ and CSR) have positively significant to firm performance is accepted.

Model 3 reveals the relationship between financial and nonfinancial variables to firm performance of Thailand dataset. The results show that MVA, EQ, and CSR have positively significant relationship to the firm performance, while IO has negatively significant relationship effect to the firm performance. ROE, EPS, and AC do not have significant relationship to the firm performance. So, the statement of hypo-thesis 3 about financial (MVA) and non-financial variables (EQ, IQ and CSR) have positively significant to firm performance is accepted.

In Thailand company, the coefficient of Adjusted R Square of model 1 is 0.4990 . It means that 49.90 percent of firm performance can be explained by return on equity, earnings per share, and market value added as independent variables, while the rest can be explained by other factors. Moreover, the coefficient of Adjusted R Square of model 2 is 0.0390. It means that 3.90 percent of firm performance can be explained by earnings quality, institutional ownership, meeting of audit committee, and corporate social responsibility as independent variables, while the rest can be explained by other factors. Furhermore, the coefficient of Adjusted R Square of model 3 obtained is 0.5490 . It means that 54.90 percent of firm performance can be explained by return on equity, earnings per share, market value added, earnings quality, institutional ownership, meeting of audit committee, and corporate social responsibility as independent variables, while the rest can be explained by other factors.

Based on the three models in this study, model (3) has the most goodness of fit. This is because the third model has the highest value of adjusted $\mathrm{R}$ square of is 0.5490 , whereas the first model of 0.4990 and the second model of 0.0390 . It means that 54.90 percent of firm performance can be explained by financial and non-financial variables as independent variables, while the rest can be explainnned by other factors.

Based on data in Indonesia, the financial variables that is not significant is ROE. It is implied that
ROE can not predict the firm performance in Indonesia so business companies especially manufacturing companies in Indonesia can not use it to predict their company performance. The size of the successful achievement of these reasons is the number ROE achieved. The bigger the ROE reflects the company's ability to generate high returns for shareholders. The result is not support research by Ardimas and Wardoyo (2014), Febriana (2013), and Amri (2011) that shows significant results. However, non financial variables that is not significant are Independence Comitte, Audit Commitee, and Corporate Social Responsibility (CSR). It is implied that the firm performance cannot be explained by Independence Comittee and Audit Commitee so business companies in Thailand can not be used these two variables to predict or explained the fluctuation of their company performance. They serve as a counter-weight in decision making and act solely for company interest that will increase firm value. This result is not prove the study by Siallagan and Machfoedz (2006), Mendra and Widanaputra (2012), Debby et al. (2013) and Mendra and Widanaputra (2012). Nevertheless, in Indonesia, the significant financial variables are EPS and MVA. Business companies especially manufacturing companies in Indonesia can use them to predict their company value. It is support research by Yulistiana (2009) find that EPS has positively significant to firm performance and Aditiya (2013) indicated that MVA has positively significant to firm performance.

Moreover, non financial variables that is significant in Indonesia are EQ and IQ. Business companies can be used this two varibeles to predict or explained the fluctuation their company value performance in Indonesia. The earnings quality will affect market response to corporate profits (Choi and Jeter, 1990). Implementation of good corporate governance is expected to improve the market's perception of the quality of corporate profits. Improving the earnings quality will be followed by increase market response to earnings surprises. It is support study by Siallagan (2009) and Mendra and Widanaputra (2012). High levels of institutional ownership in companies will lead to greater business security conducted by institutional investors. The higher ownership by financial institutions, it will increase firm value. It is support study by Rachmawati and Triatmoko (2007) and Debby et al. (2013). Furthermore, CSR is significant to firm performance in Indonesia. Investors will consider CSR activities that are disclosed in company annual report before deciding whether to invest or not. CSR disclosure is expected to increase investor trust 
to the company prospect. implementing CSR, company expected will gain social legitimacy and maximize strength finances in long term (Kiroyan,2006). It indicates that market wili respond positively company that implement CSR. It is not support research by Orlitzky et al. (2003) in Karim (2013), Ardimas and Wardoyo (2014), Febriana (2013), Amri (2011), Balabanis, Phillips, and Lyall (1998).

Based on the data in Thailand, the financial variabel that is not significant are EPS and ROE. It is implied that ROE can not predict the firm performance in Thailand so business companies especially manufacturing companies in Thailand can not use it to predict their company value. The size of the successful achievement of these reasons is the number ROE achieved. The bigger the ROE reflects the company's ability to generate high returns for shareholders. The result is not support research by Ardimas and Wardoyo (2014), Febriana (2013), and Amri (2011) that shows significant results. Moreover, Improving the earnings quality will be followed by increase market response to earnings surprises. This result is not support study by Yulistiana (2009).

The result of relationship between MVA and firm performance from Thailand Models has significant relationship. MVA is a measure used to measure success in maximizing shareholder value by allocating resources - the appropriate source. MVA also can measure how much wealth the company that has been created for investors or MVA express how much wealth has been achieved (Husniawati, 2004). It is support result by Aditiya (2013) indicated that MVA has positively significant to firm performance.

However, non financial variables that is not significant in Thailand are Independence Comitte, Audit Comiitee and Corporate Social Responsibility. It means that business companies can not be used these variables to predict or expla-ined the fluctuation the firm value performance. CSR does not have effect to firm performance in Thailand. CSR disclosure is expected to increase investor trust to the company prospect. By imple-menting CSR, company expected will gain social legitimacy and maximize strength finances in long term (Kiroyan,2006). It indicates that market will not respond positively company that implement CSR. It is not support research by Orlitzky et al. (2003) in Karim (2013), Ardimas and Wardoyo (2014), Febriana (2013), Amri (2011), Balabanis, Phillips, and Lyall (1998).

Moreover, Earning Quality and Institutional Ownership has significant relationship to firm per- formance. Earnings quality will affect market response to corporate profits (Choi and Jeter, 1990). Implementation of good corporate governance is expected to improve the market's perception of the quality of corporate profits. It is support study by Siallagan (2009) and Mendra and Widanaputra (2012). Furthermore, High levels of institutional ownership in companies will lead to greater business security conducted by institutional investors. The higher ownership by financial institutions, it will increase firm value. It is support study by Rachmawati and Triatmoko (2007) and Debby et al. (2013).

\section{CONCLUSION}

In comparison between Thailand and Indonesia, EPS is not significant for Thailand company, but it's positively significant for Indonesia company. MVA is positively significant to firm performance for both Thailand and Indonesian companies. ROE is not significant to firm performance for both Thailand and Indonesian company. However, EQ is positively significant for Thailand but negatively significant for Indonesia. Similarly, we found that IO is positively significant for Indonesia but negatively significant for Thailand. Both IC and AC are not significant in Thailand and Indonesia. CSR is positively significant for Thailand but not significant for Indonesia.

This research has significant impact to business community. Although not all variables does not have significant effect to firm performance, Business companies especially manufacturing companies in Indonesia can use EPS and MVA to predict their company performance. The earnings quality will affect market response to corporate profits (Choi and Jeter, 1990). Implementation of good corporate governance is expected to improve the market's perception of the quality of corporate profits. Improving the earnings quality will be followed by increase market response to earnings surprises. With higher earnings quality (lower discretionary accrual) will be responded positively by a third party, thus the value of the company will be higher.

Moreover, high levels of institutional ownership in companies will lead to greater business security conducted by institutional investors. The higher ownership by financial institutions, it will increase firm performance. Futhermore, Implementing CSR, company expected will gain social legitimacy and maximize strength finances in long term (Kiroyan, 2006). It indicates that market wili respond positively companies that implement CSR. 
Based on the analysis and discussion and conclusions, the limitation for this research are: first, the data conducted from 2011 to 2013 and only manufacturing companies, so more number of samples and longer observation years can be used by next researchers. Second, others financial variable besides return on equity, earnings per share, and market value added can be used by next researchers. Third, others corporate governance mechanism besides earnings quality, institutional ownership, audit committee and proportion of independent commissioner as independent variables and use other measurement for each mechanism can be used by next researchers. Finally, other parties in determining the extent of CSR disclosure as a reexamination can be involved by next researchers.

\section{REFERENCES}

Amri, C. 2011. Analysis of The Influence Financial Performance, Good Corporate Governance and Corporate Social Respon-sibility of Companies. (Online). http://library.gunadarma.ac.id accessed in September 2013.

Ardimas and Wardoyo. 2014. Pengaruh Kinerja Keuangan dan Corporate Social Responsibility terhadap Nilai Perusahaan Bank GO Publik yang Terdaftar di BEI. BENEFIT Jurnal Manajemen dan Bisnis, 18 (1), 57 - 66.

Barnhart, S. and S. Rosenstein. 1998. Board Composition, Managerial Ownership and Firm Performance: An Empirical Analysis. The Financial Review, 33 (4), November 1998. (Online). http://papers.ssrn.com accessed in December 2013.

Brigham, E. F. and J. F. Houston. 2006. DasarDasar Manajemen Keuangan, alih bahasa Ali Akbar Yulianto, Buku Satu, Edisi Sepuluh. Jakarta : Salemba Empat.

Debby, J. F., Mukhtaruddin, E. Yuniarti, D. Saputra, and Abukosim. 2013. The Effect of Good Corporate and Company's Characteristics to Firm's Value of Listed Banking at Indonesian Stock Exchange. Paer was Presented at $3^{d}$ Annual International Conference on Accounting and Finance. May 20 - 21, 2013 in Bangkok, Thailand.

Dechow, P., W. Ge and C. Schrand. 2010. Understanding earnings quality: A review of the proxies, their determinants and their consequences". Journal of Accounting and Economics, 50 (2), 344-401.

Febriana. 2013. Pengaruh Return on Equity Terhadap Nilai Perusahaan Dengan Pengungkapan
Corporate Social Responsibility Seba-gai Variable Pemoderasi pada Perusahaan Dalam Jakarta Islamic Index (JII) Periode 20092011. Skripsi, Universitas Islam Negeri Sunan Kalijaga.

Ghozali, I. and A. Chariri. 2007. Teori Akuntansi. Semarang: Penerbit Universitas Diponegoro.

Ghozali, I. 2005. Analisis Multivariate dengan Program SPSS. Semarang: Penerbit Universitas Diponegoro.

Ghozali, I. 2009. Ekonometrika Teori, Konsep dan Aplikasi dengan SPSS 17. Semarang: Penerbit Universitas Diponegoro.

Indonesia Stock Exchange. (Online). www.idx.co.id. ISO 26000 Handbook. (Online). www.ecologia.org. Karim, N. K., Mukhtaruddin, T. Marwah, Abukosim, and Y. Saftiana. 2013. The Quality of Voluntary Corporate Social Responsibility Disclosure Effect on The Firm Value of Service Companies Listed in The Indonesian Stock Exchange". Paper was Presented at $3^{\text {rd }}$ Annual International Conference on Accounting and Finance. May 2021, 2013 in Bangkok, Thailand

Komite Nasional Kebijakan Governance. Pedoman Umum GCG Indonesia. 2006. (Online). (www.ecgi.org accessed in September 2013).

Martono dan H. Agu. 2005. Manajemen Keuangan, Edisi Pertama, Cetakan ke Empat. Jakarta: Jala Sutia.

Mendra, N. P. Y. and A. A. G. P. Widanaputra. 2012. Pengaruh Corporate Governance Pada Kinerja Perusahaan. JUARA: Jurnal Riset Akuntansi, 2 (1),

Nazaruddin, I. 2000. Pengukuran Kinerja Non Finansial: Suatu Cara meningkatkan 'Value' Perusahaan. Jurnal Akuntansi dan Investasi, 1 (1), 32-40.

Rachmawati, A. and H. Triatmoko. 2007. Analisis Faktor-Faktor yang Mempengaruhi Kualitas Laba dan Nilai Perusahaan. Paper was Presented at Simposium Nasional Akuntansi X. Makasar.

Sayekti, Y. and Wondabio. 2007. Pengaruh CSR Disclosure Terhadap Earning Response Coefficient. Paper was Presented at Simposium Nasional Akuntansi X. Makasar.

Siegel, D. S. and C. J. M. Paul. 2006. Corporate Social Responsibility and Economic Performance. Springer Science and Business Media, 26, 207-211.

Siallagan, H. and M. Machfoedz. 2006. Mekanisme Corporate Governance, Kualitas Laba, dan Nilai Perusahaan. Paper was Presented at Simposium Nasional Akuntasni IX. Padang. 
Siallagan. 2009. Pengaruh Kualitas Laba Terhadap Nilai Perusahaan. Jurnal Akuntansi Kontemporer, 1 (1), 21-32.

Sugiyanto, E. K. 2011. Peningkatan Return Saham dan Kinerja Keuangan melalui Corporate Social Responsibility dan Good Corporate Governance. Aset, 13 (1), 47-56.

Undang-Undang No. 40 Tahun 2007 tentang Perseroan Terbatas

Wahyudi, U. and H. Pawestri. (2006). Implikasi Struktur Kepemilikan Terhadap Nilai Perusahaan Dengan Keputusan Keuangan Sebagai Variabel Inetrving. Paper was Presented at Simposium Nasional Akuntansi IX, Padang.

Yulistiana. 2009. Pengaruh Earnings per Share (EPS), Return on Asset (ROA), dan Arus Kas Operasi, terhadap Nilai Perusahaan (Pada Perusahaan yang Terdaftar di Jakarta Islamic Index Tahun 2004-2006). Skripsi, Universitas Islam Negeri Sunan Kalijaga. 